\title{
Repeatable timing of northward departure, arrival and breeding in Black-tailed Godwits Limosa l. limosa, but no domino effects
}

\author{
Pedro M. Lourenço • Rosemarie Kentie • \\ Julia Schroeder • Niko M. Groen • \\ Jos C. E. W. Hooijmeijer • Theunis Piersma
}

Received: 29 October 2010/Revised: 15 January 2011/Accepted: 31 March 2011/Published online: 27 April 2011

(C) The Author(s) 2011. This article is published with open access at Springerlink.com

\begin{abstract}
When early breeding is advantageous, migrants underway to the breeding areas may be time stressed. The timing of sequential events such as migration and breeding is expected to be correlated because of a "domino effect", and would be of particular biological importance if timings are repeatable within individuals between years. We studied a colour-marked population of Black-tailed Godwits Limosa l. limosa both on staging areas in Portugal and on breeding areas in The Netherlands. For each individual, we measured the timing of the staging period, the arrival date on the breeding area and the egg laying date. We measured average egg volume as a measure of reproductive investment. The date of departure from the staging areas, the arrival date on the breeding areas, and the egg laying date
\end{abstract}

Communicated by F. Bairlein.

P. M. Lourenço $(\bowtie) \cdot$ R. Kentie - J. Schroeder .

N. M. Groen · J. C. E. W. Hooijmeijer · T. Piersma

Animal Ecology Group, Centre for Ecological and Evolutionary

Studies (CEES), University of Groningen, P.O. Box 11103,

9700 CC Groningen, The Netherlands

e-mail: p.m.g.lourenco@gmail.com

Present Address:

P. M. Lourenço

Centro de Estudos da Avifauna Ibérica (CEAI),

Rua do Raimundo 119, Apartado 535,

7002-506 Évora, Portugal

Present Address:

J. Schroeder

Department of Animal and Plant Sciences,

University of Sheffield, Sheffield S10 2TN, UK

T. Piersma

Department of Marine Ecology,

Royal Netherlands Institute for Sea Research (NIOZ),

PO Box 59, 1790 AB, Den Burg, Texel, The Netherlands were repeatable among years in individual Black-tailed Godwits. The arrival dates of paired males and females and the average annual male and female arrival dates were correlated. The dates of departure from Portugal, arrival in The Netherlands, and egg laying were not correlated. Earlier clutches had larger eggs than late clutches. If the length of the individually available pre-laying period is accounted for, early arriving birds spent more time on the breeding grounds before laying than late arriving birds. The repeatability of the itineraries and the correlation between arrival timing of males and females are consistent with observations in other migrants. Despite evidence for early breeding being advantageous, we found no evidence of a "domino effect".

Keywords Cross-season interactions .

Migration ecology $\cdot$ Repeatability $\cdot$ Staging $\cdot$ Timing

Zusammenfassung Langstreckenzieher stehen unter starkem Zeitdruck wenn ein früher Brutzeitpunkt vorteilhaft ist. Es wird angenommen, dass der Zeitpunkt von Abflug, Ankunft und Eiablage von individuellen Vögeln wiederholbar zwischen den Jahren ist. Deshalb kann man erwarten, dass die Zeitpunkte dieser sequentiellen Ereignisse miteinander korrelieren: der "Dominoeffekt". We untersuchten eine mit Farbringen markierte Uferschnepfen Population in den Rastgebieten in Portugal und im Brutgebiet in den Niederlanden. Wir wissen für jedes Individuum sowohl den Zeitraum des Aufenthalts im Rastgebiet, den Ankuftszeitpunkt im Brutgebiet, und das Eiablagedatum. Wir verwandten das durchschnittlichen Eivolumen, welches mit dem Bruterfolg korreliert, als Indikation für reproduktive Investition. Innerhalb individueller Vögel waren sowohl Abflugzeitpunkt aus den Rastgebieten, Ankunft im Brutgebiet und Eiablagedatum wiederholbar 
zwischen den Jahren. Die Ankunftszeitpunkte von später verpaarten Männchen und Weibchen, sowie die durchschnittlichen jährlichen Ankunftszeitpunkte beider Geschlechter waren miteinander korreliert. Abflugszeitpunkt aus den Rastgebieten, Ankunftszeitpunkt im Brutgebiet und Eiablagedatum waren jedoch nicht miteinander korreliert. Frühe Gelege enthielten größere Eier als späte Gelege. Früh ankommende Vögel hielten sich länger im Brutgebiet auf als spät ankommende Vögel, selbst wenn wir für die Dauer des Aufenthaltes korrigierten. Die Wiederholbarkeit des Zugzeitplans und die Korrelation zwischen den Geschlechtern sind im Einklang mit Beobachtungen an anderen Zugvogelarten. Trotz des offensichtlichen selektiven Vorteils eines frühen Eiablagedatums fanden wir keine Hinweise auf einen Dominoeffekt.

\section{Introduction}

Avian migrations are often portrayed as periods of severe time constraint. This is particularly so during the migration to the breeding grounds (Farmer and Wiens 1998), as birds need to arrive early at their breeding sites (Kokko 1999; Drent et al. 2006). Early-arriving birds tend to have higher breeding success than birds arriving later (e.g. Hötker 2002; Smith and Moore 2005), as they may have better chances to acquire the best territories and nest sites (Myers 1981; Oring and Lank 1982; Drent et al. 2003), and will have time to re-nest should the first attempt fail (Reynolds et al. 1986). In income breeders, i.e. birds which use nutrients obtained at the breeding area to produce eggs, early birds will have more time to collect the necessary nutrients for egg production (Drent 2006). Finally, early chicks are often more likely to survive (Drent et al. 2006). On the other hand, early arrival at the northern breeding sites might expose birds to the risk of unpredictable weather and scarceness of food resources (Møller 1994; Drent et al. 2006). Early arrival in a year may also have costs in terms of lower productivity and delayed arrival in the subsequent year (Tryjanowski and Sparks 2008). Despite this, not all migratory systems are time constrained. Some populations have evolved towards minimising the energy spent during migration, instead of minimising time (Alerstam and Lindström 1990), thus using energy as the main fitness currency. Still, the urge to breed early leads most migrants to minimise time during the migration to the breeding grounds, even those that do not seem to do so when migrating towards the wintering grounds (Farmer and Wiens 1998).

In a few migration systems, the timing of individuals has now been shown to be repeatable among successive years, including at departure from the non-breeding grounds (Rees 1989; Battley 2006), upon arrival on the breeding areas
(Møller 2001; Hötker 2002; Bêty et al. 2004), and upon arrival on the non-breeding grounds (Rees 1989). Some studies have failed to find repeatable timing in migrants and explain this lack either to changes with age (Potti 1998) or to changes in territory quality (Forstmeier 2002).

The annual life-cycles of migrants can be seen as a series of interconnected sequential events (Piersma 1987; Buehler and Piersma 2008). The stages leading to the breeding season start in the winter quarters when birds fuel-up prior to departure, followed by migratory flights when the stored energy is spent, migratory staging when further fuelling takes place, arrival on the breeding grounds and, finally, the start of the breeding process. With time being of the essence, the timing of each event is likely to depend on the timing of the previous events (e.g. Marra et al. 1998; Norris et al. 2003). Piersma (1987) coined the term "domino effect" for the connectedness between these sequential life-cycle stages. An individual that leaves late from the winter quarters will not be expected to be among the earliest arriving on the breeding grounds, or among the earliest breeders.

Habitat quality can affect fuelling rates and, consequently, the individual timing of departure from the nonbreeding grounds (Marra et al. 1998; Piersma et al. 2005) and arrival on the breeding grounds (Gill et al. 2001; Norris et al. 2003). Individual differences in migratory timing can also be explained by age or systematic differences between sexes (Vergara et al. 2007; Cooper et al. 2009). In most migrants, the males are earlier than females, a condition known as protandry (Morbey and Ydenberg 2001). Protandry has been associated with competition for territories (Morbey and Ydenberg 2001) and high levels of sperm competition (Kokko et al. 2006). In Icelandic Black-tailed Godwits Limosa limosa islandica, paired males and females have been shown to have synchronised arrival schedules, even though males are a few days ahead of females (Gunnarsson et al. 2004).

If individual schedules are consistent between years, and if the timing of sequential migratory events is correlated and has fitness consequences, individuals would be "trapped" in seasonal cycles that would intensify fitness inequalities; in the fullness of time, natural selection would fine-tune the schedules of each population. Nevertheless, as usual even with fitness-correlated traits (Houle 1992), there remains significant variability between individuals, even within the same sex (e.g. Hötker 2002; Petersen 2009).

We present detailed data on the timing of staging during northward migration, and on the timing of arrival and breeding 2,000 km further north, of individually marked Black-tailed Godwits. We aim to (1) investigate whether individual schedules are repeatable between years, (2) determine if males and females arrive synchronously, (3) determine if the timing of sequential life cycle events are 


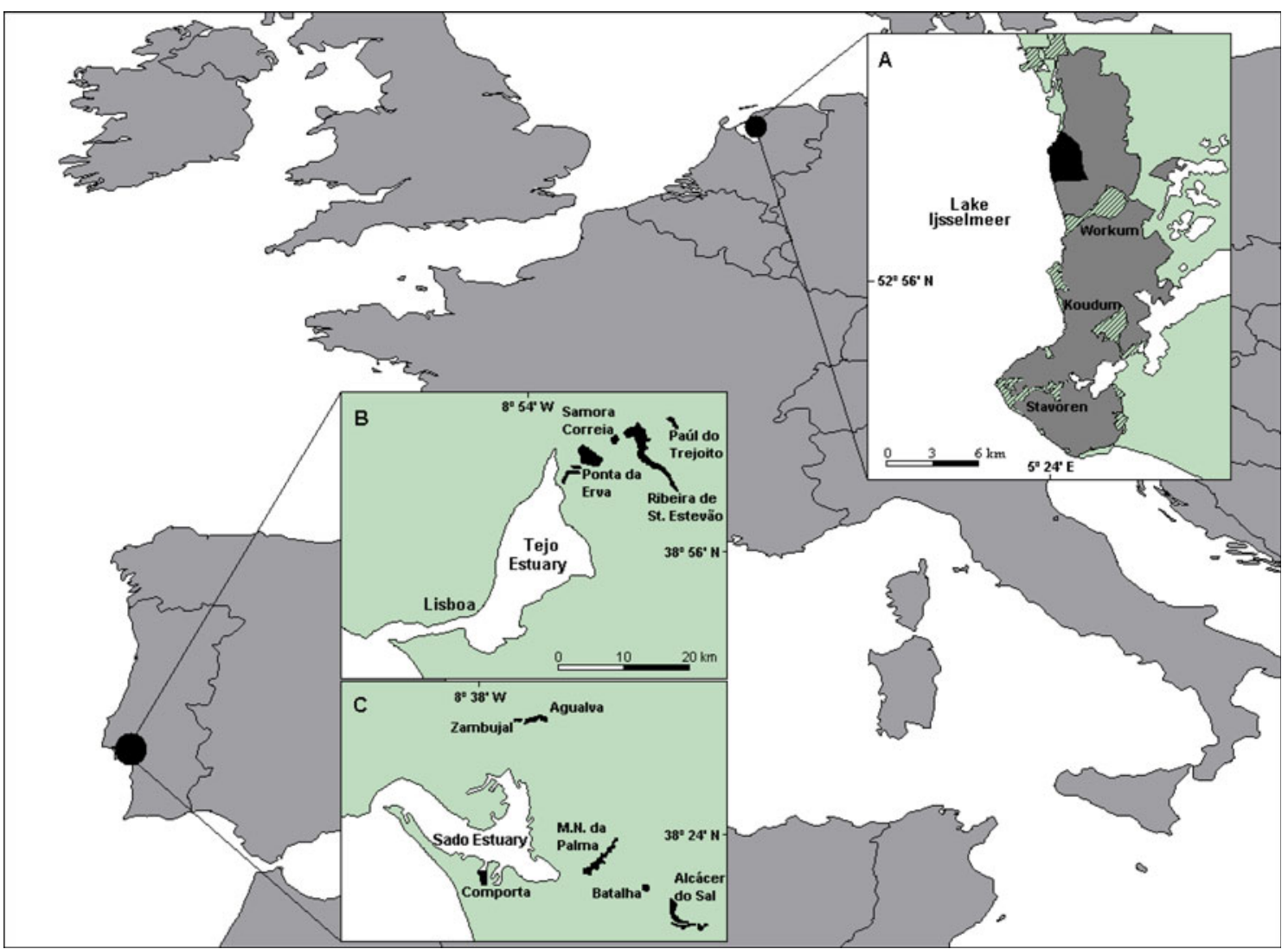

Fig. 1 The locations of the staging areas of Black-tailed Godwits Limosa l. limosa in Portugal and the breeding area in Friesland, The Netherlands. a The study area in Friesland showing the core study site (Workumerwaard) (black) monitored between 2004 and 2009 and the

correlated, and (4) we discuss whether differences in timing could have fitness consequences.

\section{Methods}

\section{Study population}

The continental subspecies of the Black-tailed Godwit is long-lived, believed to be mostly monogamous and forms stable pairs that can last for several years (Groen 1993). It is a ground-nester and with biparental care until fledging (Cramp and Simmons 1983). They breed in the agricultural grasslands of northern Europe. The Netherlands holds almost half the population (Thorup 2006). This population winters in West Africa, using rice fields and the few remaining natural wetlands as foraging habitat (Beintema et al. 1995; Zwarts et al. 2009). During northward migration, from late December to early March, these godwits stage in rice fields on the Iberian Peninsula (Masero et al. 2009; Lourenço et al. 2010a, b), where they mostly feed on spilled rice grains (Lourenço and Piersma 2008a). area monitored between 2006 and 2009 (dark grey); dashed areas represent urban areas. $\mathbf{b}, \mathbf{c}$ The study areas around the estuaries of the Tejo and Sado rivers showing the monitored rice field areas (black)

\section{Staging area}

The rice fields around the Tejo $\left(38^{\circ} 57^{\prime} \mathrm{N}, 8^{\circ} 54^{\prime} \mathrm{W}\right)$ and Sado $\left(38^{\circ} 24^{\prime} \mathrm{N}, 8^{\circ} 38^{\prime} \mathrm{W}\right)$ river estuaries, in the central western coast of Portugal, are one of the key staging areas in Iberia for Black-tailed Godwits (Lourenço et al. 2010a, b). In the four winters 2005-2006 to 2008-2009, all the rice cultivations used by godwits in the area (Fig. 1) were intensively surveyed throughout the staging period and godwit flocks were monitored for colour-rings.

To establish the individual timing of staging we used two measures: the median date of all sightings of an individual in the staging area, and the date of the last sighting of an individual at the staging area. All rice fields were visited 3-4 times per week, which yielded a re-sighting probability of $0.30 \pm 0.04$ per week (Lourenço et al. 2010a, b). In the subsequent analyses, we used all available information, even if the individual was only sighted once during the whole staging period of a particular year. We also used a smaller dataset for the analyses, using only the birds sighted at least twice and at least three times. As they all foraged in large flocks at the same few locations, and as 
the search effort was spread among these locations, we have no reason to believe that the probabilities of detection were biased against particular classes of individuals.

\section{Breeding area}

Since 2004, we have monitored birds breeding in the Workumerwaard $\left(52^{\circ} 59^{\prime} \mathrm{N}, 5^{\circ} 24^{\prime} \mathrm{E}\right)$, a ca. 400 -ha area partially managed for meadow birds. While this remained the core study site, from 2006 to 2009 the area searched for colour-ringed birds was expanded to cover a total area of c. 8,000 ha in the south-west of the province of Friesland, The Netherlands (Fig. 1). Since 2004, adults captured on the nest in late incubation received individual colour-ring combinations (Schroeder et al. 2008; van den Brink et al. 2008).

Each year, from the beginning of March, this area was under intense daily surveillance to detect arriving colourmarked birds. At this time, the grass is short and the longlegged Black-tailed Godwits ranging in small groups are easy to find and their rings detected and read. The re-sighting probabilities at the breeding area were much higher than the ones at the staging areas, averaging $0.24 \pm 0.02$ per day or $0.83 \pm 0.09$ per week (van den Brink et al. 2008). However, from the second week of April, the re-sighting effort was reduced because more time was spent on monitoring nests. We thus confined our analysis to individuals that were seen three times or more before 15 April each year. We are confident that arriving individuals were sighted within a few days of arrival within our study area in Friesland.

From April onwards, local volunteers and our professional team thoroughly searched the area for nests of ground-nesting meadow birds, and reported the approximate location of all Black-tailed Godwit nests. We then visited each nest, determining its precise location with a GPS. We measured the width and length of the eggs, in order to calculate their volume (Preston 1974). The eggs were floated in water to measure their buoyancy, which was used to determine the incubation stage and thus estimate both the laying date of the first egg and the hatching date assuming an incubation period of 25 days (Liebezeit et al. 2007). A small digital video camera was placed near every nest to identify whether the parents were colour-marked, and if so, to identify which individuals attended the nest (van den Brink et al. 2008). In the final days before hatching, the nests were visited again, to catch the adults, which were ringed and measured, and to determine whether the nest had successfully hatched. The few cases of re-nesting detected $(n=3)$ were excluded from the present analysis. Adults were sexed on the basis of plumage and body size (Schroeder et al. 2008), later verified by molecular assays using blood samples collected when they were caught (Schroeder et al. 2010a).

Repeatability in departure, arrival and breeding in males and females

We tested the expectation that the individual migratory timings are repeatable within individuals between years. We calculated repeatabilities following Lessells and Boag (1987) for three distinct measures of timing: the date of last sighting on the staging grounds, interpreted as the departure date; the date of first sighting on the breeding grounds, interpreted as the arrival date; and the egg laying date. In all three cases, we did this separately for males and females. SEs were calculated following Becker (1984).

We compared the annual average arrival date of all males and females. Also, we made a pair-wise comparison of the average arrival dates of individuals known to be paired. Finally, we tested whether, in both cases, male and female arrival dates were correlated. We did this by using reduced major axis regression, to account for the variance in the arrivals of both males and females. Reduced major axis regressions allows variability in both variables to be accounted for, and is a better method than ordinary least squares when, as it is the case in our dataset, both variables have the same scale and expected error distribution (Fig. 2).

\section{Correlation between timing of sequential} events and egg volume

We tested possible correlations between the timing of the staging period, the timing of arrival at the breeding area,
Fig. 2 Correlation between male and female arrival dates. a Average arrival date of all males and females in each study year. b Arrival dates of paired birds. Continuous lines Reduced major axis (a explained variance $=76.2 \%$, $P<0.05 ;$ b explained variance $=26.8 \%, P<0.05)$ dashed lines simultaneous arrivals $(x=y)$
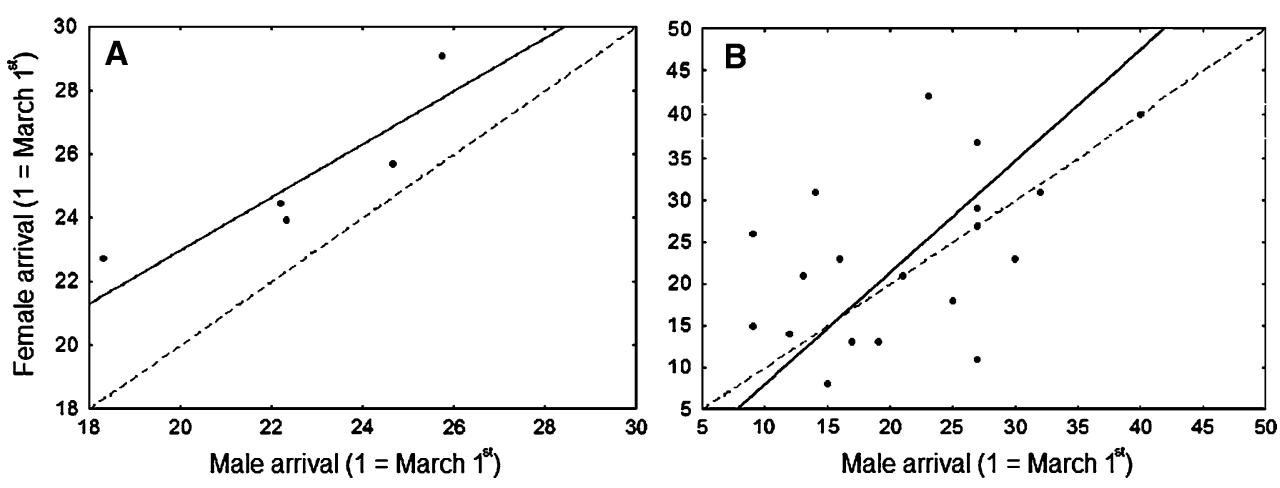
and the timing of breeding. We only used individuals for which we had data on the timing of different events in the same year. To avoid pseudo-replication, in individuals for which we had data over two or more years, we randomly selected only one year by attributing pseudo-random numbers to all years and choosing the one with the lowest figure. We used GLMs to test for an effect of the timing of an event on the timing of each subsequent event. In all cases, we used year as a factor to account for differences between years due to uncontrolled factors, like weather.

To compare the length of the pre-nesting period in birds that arrived either earlier or later in the season, we needed to account for the fact that a late arriving bird necessarily has less time to breed until the end of the season (Schroeder et al. 2010b). To gain an unbiased measure we used the proportion of the hypothetical available pre-nesting time, i.e. the time between arrival and the egg laying date of the last nest in each year that was actually used by each bird (time from arrival until laying of its own clutch). We compared this measure between the first and last quartile of arrivals (i.e. the first $25 \%$ birds to arrive and the last $25 \%$ birds to arrive).

Within a day after hatching, the long-legged chicks disappear in long grass and fledging success is difficult to determine. With 4 eggs per clutch, clutch size is fixed, so we used average egg volume per clutch as a measure of reproductive investment. Earlier, we have shown egg volume to be correlated with both the chance of hatching and the survival of fledglings (Schroeder 2010). We tested whether the timing of each event during and after migration correlated with egg volume by using GLMs for the timing of each event and using year as a factor, and again randomising to avoid pseudo-replication. We determined the statistical power of these analysss using post-hoc statistical power analysis for multiple regression which takes into account the sample size and the observed $R^{2}$, assuming $\alpha=0.05$ (Cohen et al. 2003).

\section{Results}

We found that all three timing measures (departure from staging grounds, arrival on breeding grounds and egg laying date) were significantly repeatable in individual males and females (Table 1). The individual between-year repeatability in departure date and in arrival date was higher for females than for males. Overall, males arrived on the breeding grounds on average 2.5 days earlier than females $(t=2.71, P<0.01, n=151)$ and the average annual arrival dates of males and females were correlated $\left(F_{1,3}=10.19, P<0.05, R^{2}=0.76\right.$, slope 0.81; Fig. 2a). The arrival dates of male and females known to be paired were correlated $\left(F_{1,19}=6.68, P<0.05, R^{2}=0.27\right.$, slope
Table 1 Repeatability in the date of departure from the Portuguese staging areas, arrival on the Dutch breeding area and egg laying in male and female Black-tailed Godwits Limosa l. limosa

\begin{tabular}{llllll}
\hline Stage & Sex & Repeatability & $n_{0}$ & $F$ statistic & $P$ value \\
\hline Departure & Females & $0.42 \pm 0.09$ & 2.28 & $F_{30,53}=2.17$ & $<0.01$ \\
& Males & $0.30 \pm 0.07$ & 2.62 & $F_{19,36}=2.07$ & $<0.05$ \\
Arrival & Females & $0.29 \pm 0.03$ & 3.08 & $F_{80,154}=2.28$ & $<0.001$ \\
& Males & $0.18 \pm 0.02$ & 4.06 & $F_{69,158}=1.99$ & $<0.001$ \\
Egg laying & Females & $0.18 \pm 0.04$ & 2.34 & $F_{70,163}=1.86$ & $<0.01$ \\
& Males & $0.16 \pm 0.05$ & 2.40 & $F_{48,111}=1.57$ & $<0.05$ \\
\hline
\end{tabular}

We present the repeatability $\pm \mathrm{SE}, n_{0}$ (a coefficient related to the sample size per group in the analysis of variance), and the $F$ statistic and $P$ value associated with each test

1.28; Fig. 2b), with males arriving on average 2.5 days earlier than females, with a $7 \%$ chance for this inference to be incorrect (paired $t=1.79, P=0.07, n=21$ ). This difference is identical to that found using the larger dataset of all males and females with known arrival dates, which gives strength to this result. By definition, the repeatability in egg laying was similar in both sexes, but repeatability was higher for departure dates than for the timings of arrival on the breeding grounds and egg laying.

There was considerable variation in the timing of different stages of the yearly-cycle (Fig. 3). We found no correlation between the timing of staging in Portugal and the timing of arrival on the Dutch breeding grounds or the timing of egg laying (Fig. 4). There was no effect of year. The statistical power of these analyses was high (0.72-0.97; Table 2). We also tried to correlate the median staging date and date of arrival at the breeding grounds for subsamples with just the birds seen at least twice $\left(F_{1,106}=1.89, P>0.10, R^{2}=0.10\right.$, Power 0.64) and at least three times $\left(F_{1,53}=2.35, P>0.10, R^{2}=0.07\right.$, Power $0.51)$ in the staging grounds. These confirmed the absence of a correlation, but with lower statistical power.

The first arrivals used a larger proportion of the available pre-laying intervals for the respective years before laying the first egg than the last arrivals (Mann-Whitney test: $Z=2,19, P<0.05, n=20$ ), suggesting that the first birds waited longer to start breeding than the late birds, even if corrected for the longer time they had available (Fig. 5).

Neither median staging day $\left(F_{1,36}=1.38, P>0.10\right.$, Power 0.77) nor last staging day in Portugal $\left(F_{1,36}=0.04\right.$, $P>0.50$, Power 0.68) were correlated with average egg volume. Arrival date also had no significant correlation with average egg volume $\left(F_{1,36}=0.06, P>0.50\right)$, but the power of this analysis was rather lower $(0.51)$. As we expected from previous work on this godwit population (Schroeder 2010), average egg volume was negatively correlated with egg laying date $\left(F_{1,36}=11.06, P<0.01\right)$. 

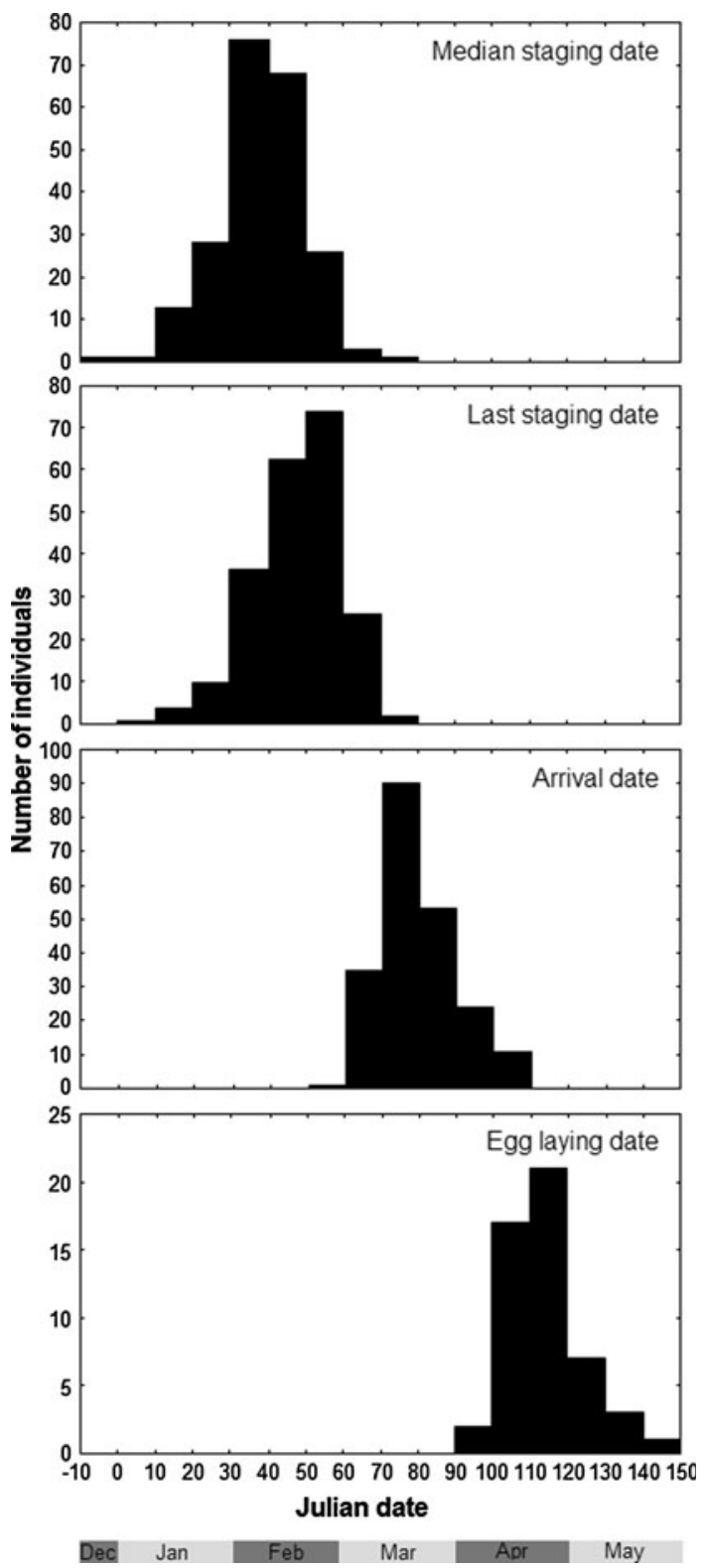

Fig. 3 Variation between individuals in the different measures of timing: median staging date and last staging date in Portugal, and arrival date and egg laying on the Dutch breeding area. The months are detailed on the $x$ axis

\section{Discussion}

We presented unique and detailed information about the timing both at staging areas and at breeding areas, coupled with reproductive parameters, for a large number of individuals in an intensely studied population of long-distance migrating shorebirds. Any study based on field observations of individual animals is to some extent limited by the probability of sighting these individuals, which may vary depending on the habitat or location they use in each stage of their yearly cycle. Low re-sighting probabilities at the staging sites can affect the reliability of the effect sizes. However, the fact that the Black-tailed Godwits almost exclusively use just a small number of rice fields at the Portuguese staging area (Lourenço et al. 2010a, b) suggests that probabilities of re-sighting will be quite similar among individuals. With their high visibility after arrival on breeding areas in The Netherlands, and the much higher re-sighting probabilities here, we cannot envisage why measures of individual timing would be biased.

Individual schedules were significantly repeatable among years, both in male and female Black-tailed Godwits. Although repeatabilities where relatively low, they were within the range of values reported in previous studies where repeatabilities were considered biologically meaningful. Repeatable arrival dates have been shown in other migratory systems, namely in Barn Swallows Hirundo rustica (Møller 2001), Garden Warblers Sylvia borin (Pulido and Berthold 2003), Snow Geese Anser caerulescens (Bêty et al. 2004) and in the Icelandic subspecies of Black-tailed Godwit Limosa l. islandica (Gunnarsson et al. 2006). The only study on departure timing from staging grounds (in Snow Geese) found no repeatability (Bêty et al. 2004), but other studies focusing on the date of departure from the wintering areas found repeatable individuals schedules in both Bewick's Swans Cygnus columbianus bewickii (Rees 1989) and Bar-tailed Godwits Limosa lapponica (Battley 2006). The egg laying dates have also been shown to be repeatable in several species including Barn Swallows (Bańbura and Zieliński 2000) and Common Guillemots Uria aalge (Sydeman and Eddy 1995). The fact that the repeatabilities of migratory timings were higher than the repeatability of egg laying dates is surprising, as one would expect the schedules to tighten towards breeding. On the other hand, migration timing may be endogenous and fixed, while breeding can be determined by local conditions that vary, so may be less repeatable. In our study population this result is likely explained by our observation that different individuals spend varying amounts of time from arrival to egg laying, which is most likely related to local causes, namely the availability of food and nesting sites.

Arrival dates of males and females were correlated, but males arrived roughly 2.5 days earlier, similar to what was described for another Black-tailed Godwit population (Gunnarsson et al. 2006). Such repeatability in individual schedules, together with the positive correlation in the arrivals of paired males and females, suggests that each individual has well characterised migratory schedules.

There is strong evidence that in our study population early breeding is advantageous, as earlier nests had a significantly higher survival probability, while both average egg volume and average chick mass, which translate into chick survival, decreased along the breeding season (Schroeder 2010). Black-tailed Godwits, like most 

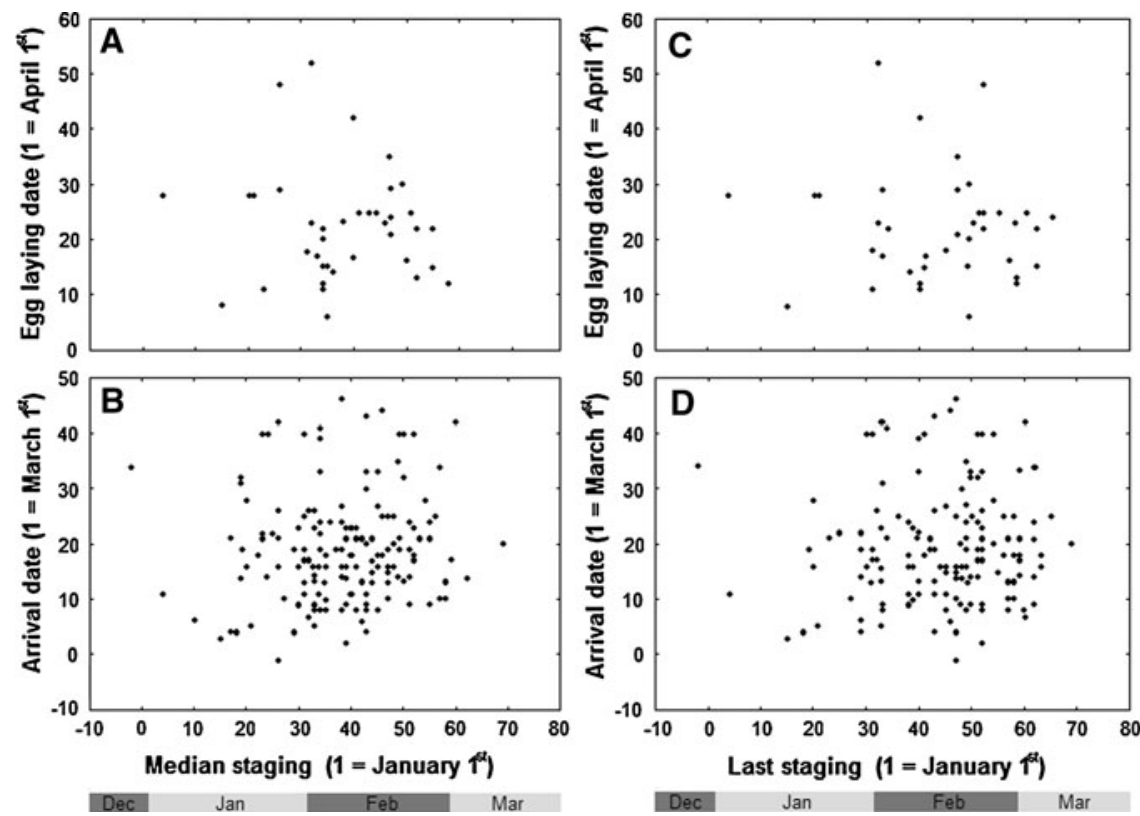

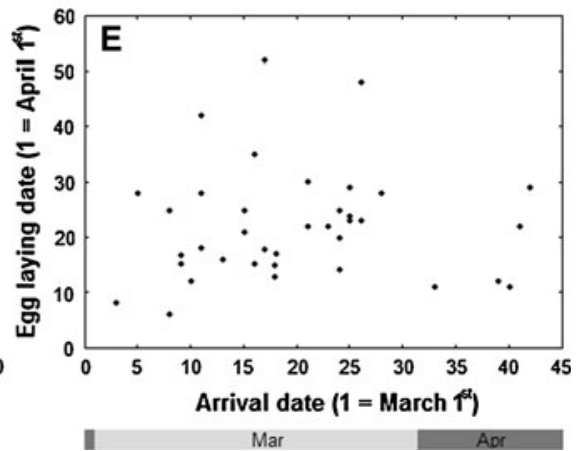

Fig. 4 Lack of correlation between the timing of different life cycle events in individual birds. The relationships between a median staging day and egg laying date, $\mathbf{b}$ median staging day and arrival

Table 2 Results of GLMs testing the correlation between timing of an event (predictor) and the timing of subsequent events (response)

\begin{tabular}{llllll}
\hline Predictor & Response & $F$ statistic & $P$ value & $R^{2}$ & Power \\
\hline Median staging & Arrival & $F_{1,149}=2.19$ & $>0.10$ & 0.06 & 0.79 \\
Last staging & Arrival & $F_{1,149}=0.35$ & $>0.50$ & 0.07 & 0.74 \\
Median staging & Egg laying & $F_{1,38}=0.01$ & $>0.50$ & 0.18 & 0.72 \\
Last staging & Egg laying & $F_{1,38}=0.12$ & $>0.50$ & 0.22 & 0.81 \\
Arrival & Egg laying & $F_{1,38}=0.15$ & $>0.50$ & 0.34 & 0.97
\end{tabular}

We present the $F$ statistic, $P$ value, $R^{2}$ and the statistical power of each analysis

Charadriiformes, have a fixed clutch size (Cramp and Simmons 1983; Beintema et al. 1995), so the level of parental care and egg volume are the only ways in which these birds can adjust their investment in a clutch (Székely and Cuthill 2000; Adamou et al. 2009). In our study population, early laying females invest in larger eggs (Schroeder 2010). Nevertheless, there is considerable variation between individual schedules. Some studies suggest the birds should lay their eggs earlier than when they do (Schroeder 2010; Kleijn et al. 2010).

There are some known cases of mismatches in the timing of sequential events (e.g. Both et al. 2005), but the majority of studies that looked into this issue found that, as expected, the timing of arrival and breeding are correlated and have an effect on breeding success (e.g. Vergara et al. 2007). Our results show no correlation between the timing of the staging period and the timing of either arrival or breeding. Due to the time constraints (Marra et al. 1998; date, $\mathbf{c}$ last staging day and egg laying date, $\mathbf{d}$ last staging day and arrival date, and e arrival date and egg laying date. The months are detailed on the $x$ axis

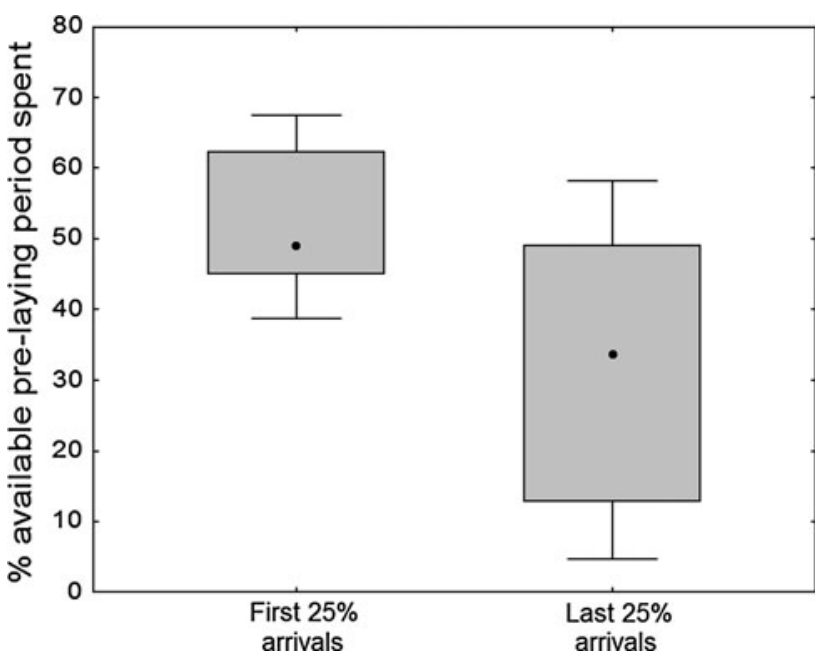

Fig. 5 Median proportion of the available pre-laying period, calculated as the proportion of the time between the arrival of each individual and the date when the last nest was layed in the respective year, used by the first $25 \%$ Black-tailed Godwits to arrive and by the last $25 \%$ to arrive before the first egg was layed in their nest. Boxes represent inter-quartile range and whiskers indicate the range

Drent et al. 2006), migrants should show "domino effects" (Piersma 1987), so the absence of a correlation between the timings of staging in Portugal and that of arrival and breeding in The Netherlands was not expected.

Individual timings in non-breeding and staging areas seem to be correlated with the timing of breeding (Marra et al. 1998; Conklin et al. 2010). Also, processes in nonbreeding and breeding areas were linked with respect to 
conditions at final wintering areas (Marra et al. 1998; Gill et al. 2001; Norris et al. 2003), and showed that the quality of wintering habitat correlated with the timing of events in the breeding areas. However, these studies have compared sub-populations using different non-breeding and breeding habitats, while our analysis focused on different individuals that use the same habitat in each stage. This change in scale could explain the absence of correlations in our study. In fact, a lack of correlation between staging timing and arrival indicates considerable inter-individual variation in the time spent travelling. Because of our large-scale and intense re-sighting effort, especially on the breeding grounds, we can confidently say that some birds left the staging areas weeks before the first arrivals in Friesland and others arrived several weeks after all birds had left the staging areas (Hooijmeijer et al. 2007; Lourenço et al. 2010a, b). Indeed, some birds were observed on their breeding territory less than a week after the last sighting in Iberia (personal observation). The variation probably reflects the relative use of further stop-overs at wetlands between Portugal and The Netherlands (Hooijmeijer et al. 2007; Lourenço and Piersma 2008b). Stopping in between can reduce the risk of facing adverse weather conditions upon arrival on the breeding grounds, namely cold spells that can freeze the soil and limit the access to soil invertebrates (Rolstad and Rolstad 1995), as these conditions will be easier to predict from a nearby staging area (Piersma et al. 1990a; Newton 2008), but, until recently, could also mean a higher mortality risk due to hunting pressure in France (Gill et al. 2007).

The lack of correlation between arrival dates and the timing of egg laying is very interesting as it contradicts observations in other migratory species. This correlation has been shown in a wide range of species from passerines (e.g. Potti 1998), to storks (e.g. Vergara et al. 2007), waders (e.g. Hötker 2002), and wildfowl (e.g. Bêty et al. 2003). A non-correlation between arrival and egg laying could originate from a lack of benefit in early breeding, which is not the case here (Schroeder 2010), or from an inability to start breeding early.

Early arriving birds waited longer before starting to breed than late arriving birds. Such a result could be an artefact if many of the earlier birds made second nesting attempts and we observed them only in their second nest. However, the observed rate of re-nesting was very low and we excluded the few cases from the analysis. That early arrival does not necessarily lead to early breeding (this paper) and that the timing of breeding seems to be later than would be expected for this population (Schroeder 2010), suggest that some factor constrains the onset of egglaying. Limited availability of food for adults, or limited availability of good quality nesting sites, could contribute to this discrepancy, both of which could be caused by large-scale habitat changes taking place due to agricultural intensification (Kleijn et al. 2010).

Overall, the absence of a domino effect indicates that the study population is not quite as time constrained as the benefits for early breeding would suggest. The migration of the continental Black-tailed Godwit is not an extremely long one, and these birds take a long time from their African wintering sites to the breeding sites. Also, they breed in temperate latitudes, where the window for breeding is much wider than that of migrants breeding in the arctic (Martin and Wiebe 2004). These facts may lead to a relaxation of the time constraints faced by this migrant. It is even possible that Black-tailed Godwits are energy minimisers during the migration to the breeding grounds, with energy, and not time, becoming the main fitness currency shaping their migratory strategies. If confirmed, this would contradict the general view that migrants tend to be time minimisers when migrating to breed (Farmer and Wiens 1998).

Black-tailed Godwits follow repeatable migratory and breeding schedules year after year which would seem to reflect a genetic basis (Pulido and Berthold 2003), but could also be explained by individual specific developmental trajectories (Gienapp et al. 2008; Teplitsky et al. 2008). In fact, phenotypic plasticity can lead to adaptations to the environment without genetic variation (Teplitsky et al. 2008). Differences between individuals are not due to "domino effects" of issues starting at or before the staging grounds in Portugal. Instead, birds differ in both the duration of their migration between the staging sites and the breeding areas, and in the duration of the time spent between arrival at the breeding sites and egg laying. One possible source of these different strategies could be social behaviour (Helm et al. 2006). Black-tailed Godwits often leave staging sites in synchronised groups, with large groups of a few to several thousands departing in the same day (Piersma 1983; Lourenço et al. 2010a, b). These large groups show increasing levels of restlessness until a clearly well-timed departure (usually just before sunset; see Piersma et al. 1990b). In the final days before departure, the majority of birds in these flocks were not even foraging (Lourenço et al. 2010a, b), apparently just getting ready for departure, possibly going through internal physiological and anatomical changes (see, e.g., Piersma 1998; LandysCiannelli et al. 2003), or simply waiting for others to be ready for migration. This seems to show that social behaviour is very important in the timing of departures in Black-tailed Godwits.

The relationships between different stages in the yearly cycle of a migrant can be much more complex than a simple cascade of domino effects. Recent advances in animal tracking, including the use of geolocators (Conklin et al. 2010) and satellite tags (Gill et al. 2009), may clarify some of the issues raised in this contribution. 
Acknowledgments We would like to thank all the landowners, both in Portugal and in Friesland, and also It Fryske Gea and Staatsbosbeheer for allowing us access to their fields. Warm thanks to the volunteers from the local "Fûgelwachten" who provided the locations of a large portion of the godwit nests used in this study and to Petra de Goeij, Valentijn van den Brink, Job ten Horn, Rinkje van der Zee, Krijn Trimbos and Ysbrand Galama for invaluable help in the field. Phil Battley provided many useful comments to a previous version of this manuscript. P.M.L. was funded by the Portuguese "Fundação para a Ciência e Tecnologia", J.S. was funded by the Schure-Beijerinck-Popping foundation and T.P. received a start-up grant from the University of Groningen.

Open Access This article is distributed under the terms of the Creative Commons Attribution Noncommercial License which permits any noncommercial use, distribution, and reproduction in any medium, provided the original author(s) and source are credited.

\section{References}

Adamou A-E, Kouidri M, Chabi Y, Skwarska J, Bánbura J (2009) Egg size variation and breeding characteristics of the blackwinged stilt Himantopus himantopus in a Saharan Oasis. Acta Ornithol 44:1-7

Alerstam T, Lindström ^̊ (1990) Optimal bird migration: the relative importance of time, energy, and safety. In: Gwinner E (ed) Bird migration: physiology and ecophysiology. Springer, Berlin, pp 331-351

Bańbura J, Zieliński P (2000) Repeatability of reproductive traits in female barn swallows Hirundo rustica. Ardea 88:75-80

Battley PF (2006) Consistent annual schedules in a migratory shorebird. Biol Lett 2:517-520

Becker WA (1984) A manual of quantitative genetics. Pulman, Washington

Beintema AJ, Moedt O, Ellinger D (1995) Ecologische atlas van de Nederlandse weidevogels. Schuyt, Haarlem

Bêty J, Gauthier G, Giroux J-F (2003) Body condition, migration, and timing of reproduction in snow geese: a test of the conditiondependent model of optimal clutch size. Am Nat 162:110-121

Bêty J, Giroux J-F, Gauthier G (2004) Individual variation in timing of migration: causes and reproductive consequences in greater snow geese (Anser caerulescens atlanticus). Behav Ecol Sociobiol 57:1-8

Both C, Bijlsma RG, Visser ME (2005) Climatic effects on timing of spring migration and breeding in a long-distance migrant, the pied flycatcher Ficedula hypoleuca. J Avian Biol 36:368-373

Buehler DM, Piersma T (2008) Travelling on a budget: predictions and ecological evidence for bottlenecks in the annual cycle of long-distance migrants. Philos Trans R Soc Lonn B 363:247-266

Cohen J, Cohen P, West SG, Aiken LS (2003) Applied multiple regression/correlation analysis in behaviorial sciences, 3rd edn. Lawrence Earlbaum, Mahwah

Conklin JR, Battley PF, Potter MA, Fox JW (2010) Breeding latitude drives individual schedules in a trans-hemispheric migrant bird. Nat Commun 1:67. doi:10.1038/1072

Cooper NW, Murphy MT, Redmond LJ (2009) Age- and sexdependent spring arrivals in eastern kingbirds. J Field Ornithol 80:35-41

Cramp S, Simmons KEL (1983) The birds of the western Palaearctic, vol. 3: hoatzin to auks. Oxford University Press, Oxford

Drent RH (2006) The timing of bird's breeding season: the Perrins hypothesis revisited especially for migrants. Ardea 94(Suppl):305-322
Drent R, Both C, Green M, Madsen J, Piersma T (2003) Pay-offs and penalties of competing migratory schedules. Oikos 103:274-292

Drent RH, Fox AD, Stahl J (2006) Travelling to breed. J Ornithol 147:122-134

Farmer AH, Wiens JA (1998) Optimal migration schedules depend on the landscape and the physical environment: a dynamic modelling view. J Avian Biol 29:405-415

Forstmeier W (2002) Benefits of early arrival at breeding grounds vary between males. J Anim Ecol 71:1-9

Gienapp P, Teplitsky C, Alho JS, Mills JA, Merilä J (2008) Climate change and evolution: disentangling environmental and genetic responses. Mol Ecol 17:167-178

Gill JA, Norris K, Potts PM, Gunnarsson TG, Atkinson PW, Sutherland WJ (2001) The buffer effect and large-scale population regulation in migratory birds. Nature 412:436-438

Gill JA, Langston RHW, Alves JA, Atkinson PW, Bocher P, Vieira NC, Crockford NJ, Gélinaud G, Groen N, Gunnarsson TG, Hayhow B, Hooijmeijer J, Kentie R, Kleijn D, Lourenco PM, Masero JA, Meunier F, Potts PM, Roodbergen M, Schekkerman H, Schroeder J, Wymenga E, Piersma T (2007) Contrasting trends in two black-tailed godwit populations: a review of causes and recommendations. Wader Study Group Bull 114:43-50

Gill RE Jr, Tibbitts TL, Douglas DC, Handel CM, Mulcahy DM, Gottschalck JC, Warnock N, McCaffery BJ, Battley PF, Piersma $T$ (2009) Extreme endurance flights by landbirds crossing the Pacific Ocean: ecological corridor rather than barrier? Proc $\mathrm{R}$ Soc Lond B 276:447-457

Groen NM (1993) Breeding site tenacity and natal philopatry in the black-tailed godwit Limosa l. limosa. Ardea 81:107-113

Gunnarsson TG, Gill JA, Sigurbjörnsson T, Sutherland WJ (2004) Arrival synchrony in migratory birds. Nature 431:646

Gunnarsson TG, Gill JA, Atkinson PW, Gélinaud G, Potts PM, Croger RE, Gudmundsson GA, Appleton GF, Sutherland WJ (2006) Population-scale drivers of individual arrival times in migratory birds. J Anim Ecol 75:1119-1127

Helm B, Piersma T, van der Jeugd H (2006) Sociable schedules: interplay between avian seasonal and social behaviour. Anim Behav 72:245-262

Hooijmeijer J, Lourenço PM, Piersma T (2007) Time to move: patterns of annual distribution and connectivity of black-tailed godwits Limosa l. limosa. Wader Study Group Bull 114:13-14

Hötker H (2002) Arrival of pied avocets Recurvirostra avosetta at the breeding site. Effects of winter quarters and consequences for reproductive success. Ardea 90(Suppl):379-387

Houle D (1992) Comparing evolvability and variability of quantitative traits. Genetics 130:195-204

Kleijn D, Schekkerman H, Dimmer WJ, van Krats RJM, Melman D, Teunissen WA (2010) Adverse effects of agricultural intensification and climate change on breeding habitat quality of black-tailed godwits Limosa l. limosa in The Netherlands. Ibis 152:475-486

Kokko H (1999) Competition for early arrival in migratory birds. J Anim Ecol 68:940-950

Kokko H, Gunnarsson TG, Morrell LJ (2006) Why female migratory birds arrive later than males? J Anim Ecol 75:1293-1303

Landys-Ciannelli MM, Piersma T, Jukema J (2003) Strategic size changes of internal organs and muscle tissue in the bar-tailed godwit during fat storage on a spring stopover site. Funct Ecol 17:151-179

Lessells CM, Boag PT (1987) Unrepeatable repeatabilities: a common mistake. Auk 104:116-121

Liebezeit JR, Smith PA, Lanctot RB, Schekkerman H, Tulp I, Kendall SJ, Tracy DM, Rodrigues RJ, Meltofte H, Robinson JA, GrattoTrevor CL, McCaffery BJ, Morse JA, Zack SW (2007) Assessing the development of shorebird eggs using the flotation method: species-specific and generalized regression models. Condor 109:32-47 
Lourenço PM, Piersma T (2008a) Stopover ecology of black-tailed godwits Limosa limosa limosa in Portuguese rice fields: a guide on where to feed in winter. Bird Study 55:194-202

Lourenço PM, Piersma T (2008b) Changes in the non-breeding distribution of continental black-tailed godwits Limosa limosa limosa over 50 years: a synthesis of surveys. Wader Study Group Bull 115:91-97

Lourenço PM, Mandema FS, Hoojmeijer JCEW, Granadeiro JP, Piersma T (2010a) Site selection and resource depletion in blacktailed godwits Limosa l. limosa eating rice during northward migration. J Anim Ecol 79:522-528

Lourenço PM, Kentie R, Schroeder J, Alves JA, Groen NM, Hooijmeijer JCEW, Piersma T (2010b) Phenology, stopover dynamics and population size of migrating black-tailed godwits Limosa limosa limosa in Portuguese rice plantations. Ardea 98:35-42

Marra PP, Hobson KA, Holmes RT (1998) Linking winter and summer events in a migratory bird by using stable-carbon isotopes. Science 282:1884-1886

Martin K, Wiebe KL (2004) Coping mechanisms of alpine and Arctic breeding birds: extreme weather and limitations to reproductive resilience. Integr Comp Biol 44:177-185

Masero JA, Santiago-Quesada F, Sánchez-Guzmán JM, Abad-Gómez JM, Villegas A, Albano N (2009) Geographical origin, return rates, and movements of the near-threatened black-tailed godwits Limosa limosa staying at a major stopover site of Iberia. Ardeola 56:253-258

Møller AP (1994) Phenotype-dependent arrival time and its consequences in a migratory bird. Behav Ecol Sociobiol 35:115-122

Møller AP (2001) Heritability of arrival date in a migratory bird. Proc R Soc Lond B 268:203-206

Morbey YE, Ydenberg RC (2001) Protandrous arrival timing to breeding areas: a review. Ecol Lett 4:663-673

Myers JP (1981) A test of three hypotheses for latitudinal segregation of the sexes in wintering birds. Can J Zool 59:1527-1534

Newton I (2008) The migration ecology of birds. Academic, London

Norris DR, Marra PP, Kyser TK, Sherry TW, Ratcliffe LM (2003) Tropical winter habitat limits reproductive success on the temperate breeding grounds in a migratory bird. Proc R Soc Lond B 271:59-64

Oring LW, Lank DB (1982) Sexual selection, arrival times, philopatry and site fidelity in the polyandrous spotted sandpiper. Behav Ecol Sociobiol 10:185-191

Petersen MR (2009) Multiple spring migration strategies in a population of Pacific common eiders. Condor 111:59-70

Piersma T (1983) Communal roosting of black-tailed godwits Limosa limosa on the Mokkebank. Limosa 56:1-8

Piersma T (1987) Hop, skip or jump? Constraints on migration of Arctic waders by feeding, fattening and flight speed. Limosa 60:185-194

Piersma T (1998) Phenotypic flexibility during migration: optimization of organ size contingent on the risks and rewards of fueling and flight? J Avian Biol 29:511-520

Piersma T, Klaassen M, Bruggemann JH, Blomert AM, Gueye A, Ntiamoa-Baidu Y, van Brederode NE (1990a) Seasonal timing of the spring departure of waders from the Banc d'Arguin, Mauritania. Ardea 78:123-134

Piersma T, Zwarts L, Bruggemann JH (1990b) Behavioural aspects of the departure of waders before long-distance flights: flocking, vocalizations, flight paths and diurnal timing. Ardea 78:157-184

Piersma T, Rogers DI, González PM, Zwarts L, Niles LJ, do Nascimento ILS, Minton CDT, Baker AJ (2005) Fuel storage rates before northward flights in red knots worldwide: facing the severest ecological constraint in tropical intertidal environments? In: Greenberg R, Marra PP (eds) Birds of two worlds: the ecology and evolution of migration. John Hopkins University Press, Baltimore, pp 262-273

Potti J (1998) Arrival time from spring migration in male pied flycatchers: individual consistency and familial resemblance. Condor 100:702-708

Preston FW (1974) The volume of an egg. Auk 91:132-138

Pulido F, Berthold P (2003) Quantitative genetic analysis of migratory behaviour. In: Berthold P, Gwinner E, Sonnenschein E (eds) Avian migration. Springer, Berlin, pp 53-77

Rees EC (1989) Consistency in the timing of migration for individual Bewick's swans. Anim Behav 38:384-393

Reynolds JD, Colwell MA, Cooke F (1986) Sexual selection and spring arrival times of red-necked and Wilson's phalaropes. Behav Ecol Sociobiol 18:303-310

Rolstad J, Rolstad E (1995) Seasonal patterns in home range and habitat use of the grey-headed woodpecker Picus canus as influenced by the availability of food. Ornis Fennica 72:1-13

Schroeder J (2010) Individual fitness correlates in the black-tailed godwit. Dissertation, University of Groningen

Schroeder J, Lourenço PM, van der Velde M, Hooijmeijer JCEW, Both C, Piersma T (2008) Sexual dimorphism in plumage and size in black-tailed godwits Limosa limosa limosa. Ardea 96:25-37

Schroeder J, Kentie R, van der Velde M, Hooijmeijer JCEW, Both C, Haddrath O, Baker AJ, Piersma T (2010a) Linking intronic polymorphism on the CHD1-Z gene with fitness correlates in black-tailed godwits Limosa l. limosa. Ibis 152:368-377

Schroeder J, Mitesser O, Hinch M (2010b) Correlations between sequential timing decisions do not necessarily indicate strategic behavior: a comment on Bêty et al. Am Nat 176. doi: $10.1086 / 657275$

Smith RJ, Moore FR (2005) Arrival timing and seasonal reproductive performance in a long-distance migratory land bird. Behav Ecol Sociobiol 57:231-239

Sydeman WJ, Eddy JO (1995) Repeatability in laying date and its relationship to individual quality for common murres. Condor 97:1048-1052

Székely T, Cuthill IC (2000) Trade-off between mating opportunities and parental care: brood desertion by female Kentish plovers. Proc R Soc Lond B 267:2087-2092

Teplitsky C, Mills JA, Alho JS, Yarrall JW, Merilä J (2008) Bergamnn's rule and climate change revisited: disentangling environmental and genetic responses in a wild bird population. Proc Natl Acad Sci USA 105:13492-13496

Thorup O (2006) Breeding waders in Europe 2000. International Wader Studies 14. International Wader Study Group, UK

Tryjanowski P, Sparks TH (2008) The relationship between phenological traits and brood size of the white stork Ciconia ciconia in western Poland. Acta Oecol 33:203-206

van den Brink V, Schroeder J, Both C, Lourenço PM, Hooijmeijer JCEW, Piersma T (2008) Space use by black-tailed godwits Limosa limosa limosa during settlement at a previous or a new nest location. Bird Study 55:188-193

Vergara P, Aguirre JI, Fernandez-Cruz M (2007) Arrival date, age and breeding success in white stork Ciconia ciconia. J Avian Biol 38:573-579

Zwarts L, Bijlsma RG, van der Kamp J, Wymenga E (2009) Living on the edge: wetlands and birds in a changing Sahel. KNNV, Zeist 